LEDER

\section{RELIGIONSPEDAGOGISKE PROFESJONSUTFORDRINGER}

Utgangspunktet for dette nummeret av Prismet er profesjonsutfordringer i det religionspedagogiske feltet. Dette er et vidløftig, men også et komplekst tema. Utfordringene for profesjonene er forskjellige i ulike praksisfelt som skole, barnehage og trossamfunn. Imidlertid er det også grunn til å tro at skole, barnehage og kirke har noen felles utfordringer og spørsmål som det er viktig å vie oppmerksomhet.

Hvorfor er profesjon viktig? En vanlig tilnærming til «profesjon» henviser til at profesjonelle skal være forvaltere av et mandat (The System of Professions, Abbot 1988). Religionspedagoger må forhandle mange typer mandat. Som Østrem og Hennum skriver i sin ferske utgivelse Barnehagelareren som profesjonsutøver (CappelenDamm 2015) skal profesjonelle representere politiske mandat så vel som verdier og spesifikk profesjonskunnskap. I dette nummeret av Prismet vil nettopp profesjonsmandat bli særlig presentert og debattert. Hilde Afdal med flere formidler noen funn fra et forskningsprosjekt om læreres og barnehagelæreres profesjonsetikk, og utfordrer blant annet til utvikling av felles profesjonsetisk språk og til faglig ansvarliggjøring og begrunnelse av handlinger. Lise Fladberg beskriver i sin artikkel hvordan kateketers virke kan overflødiggjøres av et for allmenngyldig mandat i kirken. Mens Ingeborg Tveter Thoresens artikkel problematiserer barnehagelæreres kjennskap til mandat og kunnskap om formidlingen av verdier, utfordrer Kåre Fuglseth til hvordan mandat om objektivitet og nøytralitet også løsriver utdanning fra kontekst og elevers livsverden. Imidlertid er ikke religionspedagogiske profesjonsmandat entydige eller fikserte. Prismet-nummerets forskningsartikkel setter søkelys på hvordan man kan håndtere at profesjonskunnskap og -verdier forandres og reforhandles i tid og rom i ulike kontekster. Ingrid Reite Christensen utforsker læreplaner i norsk og nederlandsk presteutdanning og beskriver hvordan prestestudenter utrustes for en sammensatt profesjonshverdag som krever evne til kunnskapsutvikling.

I dette nummeret viser forfatterne en rekke spenninger og forhandlinger som foregår mellom profesjonelle mandat og ikke-profesjonelle aktører. Ufaglærte medarbeidere, mangel på organisatorisk posisjon, styrende lærebøker, utspill og innspill fra elever, nyorienteringer $\mathrm{i}$ utdanningen og manglende kom- 
petanse $\mathrm{i}$ verdiformidlingen $\mathrm{i}$ barnehagen er alle momenter som viser hvilken kompleksitet og uforutsigbarhet som feltene skole, barnehage og kirke byr på. I tillegg til forsknings- og refleksjonsartikler bringer dette nummeret anmeldelser av to nye bøker som beskjeftiger seg med sentrale utfordringer for barnehagelærerprofesjonen: Sturla Sagbergs Holistic Religious Education - is it possible? og Solveig Østrem og Bernt Andres Hennums Barnehagelareren som profesjonsutøver.
Når jeg beskriver disse som utfordringer hos religionspedagogiske profesjoner, representerer ikke utfordringer kun umuligheter i feltet. Forhandlinger og uklarheter har også sitt potensiale for prosesser som kanskje gir religionspedagogiske profesjoner noen av sine særtrekk.

Ingrid Reite Christensen

(gjesteredaktør) 